\title{
Brand Attitude, Its Antecedents and Consequences. Investigation into Smartphone Brands in Malaysia
}

\author{
Zahra Seyed Ghorban
}

\begin{abstract}
The notion of brand attitude has been conceptualized and been the target of different empirical investigations. There are arguments regarding the antecedents and the consequences of this concept in business environment, and it is believed that there are several factors affecting brand attitude including advertisement and customer satisfaction. On the other hand brand attitude has been argued to be positively related to purchase intentions among customers. This study by analyzing smartphone brands in Malaysia found that the relationship of customer satisfaction and advertising with brand attitude is positive and significant, while the latter is positively related to purchase intention.
\end{abstract}

Keywords: Brand attitude, Customer satisfaction, Advertisements, Purchase intention.

\section{Introduction:}

Both practitioners and academicians in the business organizations have been observing numerous attentions toward understanding and conceptualizing different aspects of branding, and how this phenomenon could provide differentiation and competitive advantages for the firms have been discussed in depth. Attempts have been made extensively to study different facets of branding literature. One of the emerging concepts in branding literature is brand attitude. Studies during the past years have been trying to investigate both the antecedents and the consequences of brand attitude. Where brand attitude is formed and how it can be beneficial to different organizations have been the subjects of many empirical investigations in the business environments. It is believed that products act as a symbol to consumers, who buy them to identify and differentiate the group they belong to, and prior experiences and satisfaction with a given product is argued to be an effective tool to influence the repurchase engagement among consumers [1]. Consumers would gain positive or negative attitude (defined as "... a lasting general evaluation of people, objects, advertisement, or issues" [2]) toward an object (here brand) by having previous experience, which would bring satisfaction or dissatisfaction.

It is the main interest of this study to empirically examine a) the role consumer satisfaction and advertising play in enhancing brand attitude; and b) after the attitude toward a brand is formed how it could affect purchasing intention among consumers. This study will focus on the different brands that are active in manufacturing and distributing smartphones and at the same time providing after sale services in the country of Malaysia. The smartphones brands examined in this study are those that are highly advertised and extensively presented in the Malaysian consumer markets (such as Apple, Samsung, HTC, Nokia, Blackberry, etc.).

In the following parts literature review will be reviewed and the hypotheses will be developed; methodology will be explained; results will be elaborated; and finally the conclusions of this study will be discussed.

\section{Literature review and hypotheses development:}

The concept of attitude is very wide and many different contexts used this concept (Solomon, 2009). Attitude could be defined as "... a lasting general evaluation of people, objects, advertisements, or issue" [2]. Banyte, Jokšaite, and Virvilaite $\square$ [3] defined attitude as "an achievable, relatively permanent and at the same time purposeful, gradual, more or less intensive, and motivated consumers' intention to react to a particular object" (p. 75). Based on these definitions, it could be inferred that attitude could be made toward a particular brand of an organization, which would then be called "brand attitude" and defined as "... a consumers" overall evaluation of a brand" [4]. This attitude could be positive or negative [5,6], last for a long time and could be changed if people gain new experiences or reflections [2].

Attitude has been divided into four functions as: "utilitarian", "value-expression", "ego defensive", and "knowledge function" [7]. Solomon [2] argued that attitude includes three factors as affect, which explains the emotions and feelings toward an object; behavior, which explains the actions taken toward an object; and cognition, which explains the thoughts toward an object. Affect and cognition factors of attitude are believed to be a generalized concept of brand attitude indicating that they could be influenced by different factors such as quality, communications, and experience with a particular brand [8].

Attitude valence and strength is the long-term invocation of marketers as major antecedents of consumer behavior [6]. Park, et al. [6] defined attitude valence as "the degree of positively or negatively with which an attitude object (in the current context, a brand) is evaluated" (p. 1). Strong attitude is believed to be the 
result of effortful thoughts about the attitude object $[6,9]$ and it is mentioned, "The effortful thoughts and the confidence with which the attitude object is held guide behavior" [6], which different empirical investigations have provided supports for this notion $[10,11]$

Based on the self-expansion theory, which postulates that there are inherent motivations for selfexpression in people and they desire to integrate others (in this case brand) in what they think of as a "self" [12], it could be inferred that people express special attitude toward a brand (by having prior experience, satisfaction, etc.) to incorporate that brand into their conception of self in order to differentiate and classified themselves as a different group. The bond that connects self with an entity would become closer if more of that entity were included in the self [6].

On the other hand, marketing mix strategy has been argued to be an effective tool that enables firms to attract more customers in the competitive business environment [13], and it has been extensively investigated in different branding aspects [e.g. 14, 15]. Advertising as one of the important marketing mix efforts has been shown to be significantly related to brand attitude [16]. Scholars believed that being able to affect the perceptions that influence the brand choice is the ultimate goal of advertising [17]. In some contexts such as TV, advertising might be appropriate since Krugman [18] mentioned that "advertising might work just by changing perceptions [cognitive processing] toward the product in the course of merely shifting the relative salience of attitudes, especially when the purchaser is not particularly involved in the message" (p. 349).

Kokkinaki and Lunt [19] mentioned, "Purchase decisions typically involve a selection among different brands of a given product category. Marketing and advertising rely heavily on the formation of favorable brand attitudes as a means of promoting brand selection" (p. 42)

C. Yoo and MacInnis [20] investigated brand attitude development procedure by advertisement format whether emotional or informational. They concluded that advertisements with emotional format would diminish negative feelings while improve positive ones and enhance the thoughts around the ads' credibility that would eventually affect the brand attitudes toward that particular brand. The informational ads format also concluded to enhance positive feelings and diminish negative ones, which would affect brand attitude.

Attitude toward advertising is argued to be positively related to purchase intention [21, 22]. Hwang, Yoon, and Park [23], by investigating into web advertisements, found that response toward advertising is positively related to website attitudes, while the latter would positively influence brand attitude, which would influence purchase intention positively. They argued that after attitude toward advertisements is formed, it would affect different behaviors such as brand attitude and purchasing intention. By examining online advertisement, Y. Yoo [24] mentioned, "upon exposure to Web ads, consumers experience priming caused by implicit memory and build a more favorable attitude toward the advertised brand regardless of the levels of attention they paid to the advertisements. Furthermore, those who unconsciously processed Web ads did not remember seeing the ad explicitly, but they were more likely to include the advertised brand in the consideration set than those who had no exposure" (p. 2).

Researchers differentiate brand attitudes and satisfaction as two distinct concepts in the marketing literature [e.g. 25, 26]. Customer satisfaction is regarded as comparatively momentary and based on consumption experience, but attitudes are argued to be comparatively longer lasting than satisfaction [27].

Satisfaction is argued to be the assessment of the whole situation involved in purchasing comparative to expectation, but brand attitude is somehow a sense of liking and no sense of comparison exist in the purchase situation [28]. Empirical investigation found the positive influence of satisfaction, which rooted in past experiences, on post purchasing behaviors and attitudes [25], and some argued that attitudes should be the consequence of satisfaction. Suh and Youjae [16] also argued that indirect experiences (through advertising for instance) are able to develop brand attitude, in which these indirect experiences, advertising among them, are determinants of brand attitudes.

Keller [29] argued that firms by using tools such as advertising would send messages to their consumers in order to establish distinct, constructive, and strong associations with a product. The reaction to these attempts would define the relationships between advertisement and brand evaluations. There are arguments regarding the role of advertisement in establishing brand beliefs and feelings [22, 30, 31], and attitudes towards advertising has been found to be directly related to brand attitudes, which in turn affect purchase intentions among consumers [22].

Drawing from the above discussions on the role of advertising and customer satisfaction on brand attitudes and consequently on purchase intention, the following are hypothesized:

H1: Customer satisfaction is positively and significantly related to brand attitude.

H2: Advertising is positively and significantly related to brand attitude.

H3: Brand attitude is positively and significantly related to purchase intentions.

\section{Methods:}

\subsection{Sample:}

This study was conducted in Kuala Lumpur, Malaysia, and students from different public universities 
(convenient sampling method) participated in this study. The total number of 200 surveys distributed among students out of which 164 valid responses received and used for the analysis. All of the participants were requested to show their smartphones and anyone who did not have any popular brands of smartphone with $\mathrm{him} / \mathrm{her}$ were not asked to participate.

\title{
3.2 Measurement instruments:
}

To measure customer satisfaction participants were asked to evaluate the product (in this case the smartphones) based on six different attributes as: "immediate outcome", "process", "delayed outcome", "perceived price", and two "design-related attributes: shape and color" in a five-point Likert Scale ranging from 1 designating "very dissatisfied" to 5 designating "very satisfied" [16, 32]. Three items measured advertising as "unfavorable" to "favorable, "unappealing" to "appealing", and "unpersuasive" to "persuasive" in a five-point Likert Scale [16,32]. Attitude toward brand was measured using two items as "unfavorable" to "favorable", and "dislike" to "Like" in a five-point Likert Scale $[16,32]$. In order to measure purchase intention three items adapted from Erdem and Swait $[33,34]$ to analyze the future purchase intention engagements of the respondents that rated the same brand.

\subsection{Reliability and validity:}

Cronbach's Alpha was used to measure the reliability level of the instruments included for this study. All reliabilities were between .80 and .96 establishing that these instruments are reliable to measure the proposed variable, since all were above .60 [35].

Exploratory factor analysis (EFA) was conducted to find out if the items would produce the proposed factor and if they would load on their respective factor in a strong way. Using principal component analysis with oblique rotation technique four distinct factors were suggested and all items loaded strongly on their relevant factor. Applying orthogonal rotation approach resulted in obtaining similar result to those of oblique technique verifying convergent and discriminant validity of the instruments.

\subsection{Convergent and Discriminant validity:}

As shown in table 1 all variables in this study reached satisfactory level in both convergent and discriminant validity. For establishing convergent validity average variance extracted (AVE) should exceed .50 [36]. With regard to discriminant validity, as shown in table 2, the maximum shared squared variance (MSV) and average shared squared variance (ASV) should both be less than average variance extracted (AVE) in order to establish the discriminant validity [37]

\section{"Insert Table One Here"}

\section{Results:}

The following table (Table 2) shows the means, standard deviations, and the correlations of the variables included in this study.

\subsection{Hypotheses testing:}

"Insert Table Two Here"

Structural Equation Modeling (SEM) using AMOS 18.0 with Maximum Likelihood Estimation was used to analyze the proposed hypotheses.

\author{
"Insert Table Three Here"
}

Hypothesis one predicted that customer satisfaction would be positively and significantly related to brand attitude, and the results support the first hypothesis in its predicted direction. Advertising found to be positively and significantly related to brand attitude supporting hypothesis two in its predicted direction. The last hypothesis was also supported in which brand attitude was found to be positively and significantly related to purchase intentions.

\section{Conclusions and discussions:}

This study set out to address the issue of brand attitude its antecedents and consequences. Studies have suggested that both customer satisfaction and advertisement would influence positively on brand attitude, which would be positively related to purchase intentions behaviors among customers. This study examined these relationships in the smartphone markets in the country of Malaysia where there are high demand for current technology upgrade in this particular market. One could understand this by observing the numerous growths in the number of providers and the number of contractual service providers. Almost all telecommunication companies in this country offer contractual cellular phones from different brands such as Apple, Samsung, Nokia, HTC, etc. The market for this product and its respective services are very competitive and brands try to offer not only the best deal but also the quality products that would satisfy the customers and create positive brand attitude among them in order to engage to purchase intention while there are upgraded product available. Consistent with findings from previous investigations $[16,25,27]$, the findings from this study confirmed that advertising, as an affective marketing tools, are able to positively and significantly influence brand attitude by building a positive perception of brands in the mind of customer. Another finding from this study, confirming the previous findings, was the positive influence of customer satisfaction on building positive brand attitude, 
Brand attitude, its antecedents and consequences. Investigation into smartphone brands in Malaysia which would be positively related to purchase intentions. Studies of this kind, which examine the satisfaction and repurchase intentions, have been done in western countries [16, 38, 39] and similar results have been found. Managers, especially the ones in telecommunication industry, should bear this in mind that if they want to build strong brand attitude among their customers need to invest in advertisement activities in order to enhance the level of attitude, which would result in favorable purchase engagements. Another implication for managers is that they need to keep their customers satisfied in order to enhance the brand attitude, which again would be result in higher purchase intention.

Managers need to offer products that enhance the satisfaction level among customers in which this higher satisfaction would influence brand attitude positively. Future studies need to find how customer satisfaction is build, which result positive brand attitude. As one of the limitations of this study, this could be a good direction for future research to find the sources that bring customer satisfaction.

Future studies could also examine the relationships investigated in the current study in another contexts whether different countries or different product categories. Service industries could also be a potential target to address the issue of brand attitude how it is formed and what it affects.

\section{Reference:}

[1]. Armstrong, G. and K. Kotler, Marketing an introduction. 9th ed2009, New Jersey: Pearson Education.

[2]. Solomon, M.R., Consumer Behavior $\square$ Buying, Having and Being. 8th ed2009, New Jersey: Pearson education.

[3]. $\quad$ Banyte $\square$, J., E. Joks $\square$ aite $\square$, and R. Virvilaite $\square$, Relationship of Consumer Attitude and Brand: Emotional Aspect. Engineering Economics, 2007. 2(2): p. 65-77.

[4]. Martensen, A., et al., Application of a Model for the Effectiveness of Event Marketin. Journal of advertising research, 2007. 47(3): p. 283-301.

[5]. Currás $\square$ Peréz, R., E. Bigné $\square$ Alcañiz, and A. Alvarado $\square$ Herrera, The Role of Self $\square$ Definitional Principles in Consumer Identification with a Socially Responsible Company. Journal of Business Ethics, 2009. 89(4): p. 547-564.

[6]. Park, C.W., et al., Brand Attachment and brand Attitude Strength: Conceptual and Empirical Differentiation of Tow Critical Brand Equity Drivers. Journal of Marketing, 2010. 74(6): p. 1-17.

[7]. Katz, D., The functional approach to the study of attitudes. American Association for Public Opinion Research, 1960. 24(2): p. 163204.

[8]. VonReisen, R.D. and N.C. Herndon, Consumer Involvement With the Product and the Nature of Brand Loyalty. Journal of Marketing Channels, 2011. 18(4): p. 327-352.

[9]. Petty, R.E., B. Pablo, and K.G. D., The Meta-Cognitive Model (MCM) of Attitudes: Implications for Attitude Measurement, Change, and Strength. Social Cognition, 2007. 25(5): p. 657-686.

[10]. Fazio, R.H. and R.E. Petty, Attitudes: Their Structure, Function, and Consequences2007, New York: Psychology Press

[11]. Petty, R.E., C.P. Haugtvedt, and S.M. Smith, Elaboration as a Determinant of Attitude Strength: Creating Attitudes That are Persistent, Resistant, and Predictive of Behavior, in Attitude Strength: Antecedents and Consequences, R.E. Petty and J.A. Krosnick, Editors. 1995, Lawrence Erlbaum Associates: Mahwah, NJ. p. 93-130.

[12]. Aron, A., et al., Including Close Others in the Cognitive Structure of the Self, in Interpersonal Cognition, M.W. Baldwin, Editor 2005, Guilford Press: New York. p. 206-232.

[13]. Kotler, P., Marketing Management. 11th ed2003, Upper Saddle River, NJ: Prentice- Hall.

[14]. Buil, I., L. de Chernatony, and E. Martinez, Examining the role of advertising and sales promotions in brand equity creation. Journal of Business Research, 2011(0).

[15]. Yoo, B., N. Donthu, and S. Lee, An examination of selected marketing mix elements and brand structure. Journal of the Academy of Marketing Science, 2000. 28(2): p. 195-211.

[16]. Suh, J.-C. and Y. Youjae, When Brand Attitudes Affect the Customer Satisfaction-Loyalty Relation: The Moderating Role of Product Involvement. Journal of Consumer Psychology, 2006. 16(2): p. 145-155.

[17]. Alba, J.W., J.W. Hutchinson, and J.G. Lynch, Memory and decision making, in Handbook of consumer behavior, T.S. Robertson and H.H. Kassarjia, Editors. 1991, Prentice Hal: Englewood Cliffs, NJ. p. 1-49.

[18]. Krugman, H.E., The impact of television advertising: learning without involvement. Public Opinion Quarterly, 1965. 29(Fall): p. 349-56.

[19]. Kokkinaki, F. and P. Lunt, The effect of advertising message involvement on brand attitude accessibility. Journal of Economic Psychology, 1999. 20(1): p. 41-51.

[20]. Yoo, C. and D. MacInnis, The brand attitude formation process of emotional and informational ads. Journal of Business Research, 2005. 58(10): p. 1397-1406.

[21]. MacKenzie, S.B. and R.J. Lutz, An empirical examination of the structural antecedents of attitude toward the Ad in an advertising pretesting context. The Journal of Marketing, 1989. 53(2): p. 48-65.

[22]. MacKenzie, S.B., R.J. Lutz, and G.E. Belch, The role of attitude toward the Ad as a advertising effectiveness: a test of competing explanation. Journal of Marketing Research, 1986. 23(2): p. 130-143.

[23]. Hwang, J., Y.-S. Yoon, and N.-H. Park, Structural effects of cognitive and affective reponses to web advertisements, website and brand attitudes, and purchase intentions: The case of casual-dining restaurants. International Journal of Hospitality Management, 2011. 30(4): p. 897-907

[24]. Yoo, C.Y., Unconscious processing of Web advertising: Effects on implicit memory, attitude toward the brand, and consideration set. Journal of Interactive Marketing, 2008. 22(2): p. 2-18.

[25]. Oliver, R.L., A cognitive model of the antecedents and consequences of satisfaction decisions. Journal ofMarketing Research, 1980. 17: p. 460-469.

[26]. Oliver, R.L., Satisfaction: A behavioral perspective on the consumer1997, New York: McGraw Hill.

[27]. Oliver, R.L., Measurement and evaluation of satisfaction process in retail setting. Journal of Retailing and Consumer Services, 1981. 57: p. 25-48.

[28]. Westbrook, R.A. and R.L. Oliver, Developing better measures of consumer satisfaction: Some preliminary results, in Advances in consumer research, K.B. Monrow, Editor 1981, Association for Consumer Research: Ann Arbor, MI. p. 94-99.

[29]. Keller, K., Strategic brand management. 2nd ed2003, Upper Saddle River, NJ: Prentice Hall. 
[30]. Olney, T., M. Holbrook, and R. Batra, Consumer responses to adver- tising: The effect of ad content, emotions, and attitude toward ad on viewing time. Journal of Consumer Research, 1991. 17: p. 440-453.

[31]. Park, C.W., B.J. Jaworski, and D.J. Maclnnis, Strategic brand concept/image management. Journal of Marketing, 1986. 50: p. 135145.

[32]. Mitchell, A., The effects of visual and verbal components on brand attitudes and attitude toward the advertisement. Journal of Consumer Research, 1986. 13: p. 12-24.

[33]. Erdem, T. and J. Swait, Brand Equity as a Signaling Phenomenon. Journal of Consumer Psychology, 1998. 7(2): p. 131-157.

[34]. Erdem, T. and J. Swait, Brand Credibility and its Role in Brand Choice and Consideration. Journal of Consumer Research, 2004. 31(1): p. 191-199.

[35]. Nunnally, J.C., Psychometric theory. McGraw-Hill, New York, 1978: p. 23-45.

[36]. Fornell, C. and D.F. Larcker, Evaluating structural equation models with unobservable and measurement errors. Journal of Marketing Research, 1981. 18: p. 39-50.

[37]. Hair, J., et al., Multivariate data analysis. 7th ed2010, Upper Saddle River, NJ: Prentice Hall, Inc.

[38]. Dick, A.S. and K. Basu, Customer loyalty: Toward an integrated con-ceptual framework. Journal of the Academy of Marketing Science, 1994. 22: p. 99-113.

[39]. Oliver, R.L., Whence consumer loyalty? Journal of Marketing, 1999. 63: p. 33-44.

Tables:

Table 1: Convergent and Discriminant validity

\begin{tabular}{lccc}
\hline Constructs & AVE & MSV & ASV \\
\hline Customer Satisfaction & .805 & .116 & .070 \\
Advertising & .794 & .314 & .152 \\
Brand Attitude & .862 & .314 & .217 \\
Purchase Intentions & .824 & .221 & .101 \\
\hline
\end{tabular}

Table 2: Correlation Analysis

\begin{tabular}{lllllll}
\hline Variable & Mean & SD & 1 & 2 & 3 & 4 \\
\hline Customer Satisfaction & 4.17 & 1.01 & 1 & & & \\
Advertisements & 3.85 & 1.18 & $.27^{* *}$ & 1 & & \\
Brand Attitude & 3.84 & 1.32 & $.33^{* *}$ & $.51^{* *}$ & 1 & \\
Purchase Intention & 3.74 & 1.22 & $.22^{* *}$ & $.38^{* *}$ & $.41^{* *}$ & 1 \\
\hline
\end{tabular}

**Correlation is significant at the 0.01 level (two-tailed)

Table 3: Structural Equation results for the proposed hypotheses

\begin{tabular}{|c|c|c|c|c|}
\hline \multicolumn{2}{|r|}{ Hypotheses } & Standardized & t- & Conclusion \\
\hline H1 & $\begin{array}{l}\text { Customer } \text { Satisfaction } \rightarrow \text { Brand } \\
\text { Attitude }\end{array}$ & $.20 * *$ & 2.723 & Supported \\
\hline $\mathrm{H} 2$ & Advertising $\rightarrow$ Brand Attitude & $.51 * * *$ & 6.362 & Supported \\
\hline H3 & Brand Attitude $\rightarrow$ Purchase Intentions & $.48 * * *$ & 3.767 & Supported \\
\hline $\begin{array}{l}\text { Model } \\
\text { Fit }\end{array}$ & $\begin{array}{l}\chi^{2} / d f=83.403 / 61=1.367 ; \text { GFI }=.913 ; \\
\mathrm{RMR}=.094 ; \mathrm{RMSEA}=.047\end{array}$ & $\mathrm{AGFI}=.90$ & $\mathrm{NFI}=.96 ;$ & $\mathrm{CFI}=.99$ \\
\hline
\end{tabular}

